\title{
Culture of In Vitro Mouse Embryos with Vitamin E Improves Development
}

\author{
Hirotada TSUJII'), Masae MURANAKA ${ }^{1)}$ and Koh-ichi HAMANO ${ }^{1)}$ \\ 1)Faculty of Agriculture, Shinshu University, Minamiminowa-mura, Nagano 399-4598, Japan
}

\begin{abstract}
To investigate the effects of vitamin $\mathrm{E}$ on the in vitro development of mouse embryos from 1cell to blastocysts, embryos were cultured in two media, Brinster's BMOCIII and BMOCIII supplemented with $100 \mu \mathrm{M}$ vitamin E (BMOCIIIvitE). The incorporation and oxidation of glucose were also compared between the embryos cultured in these media. Both the number of embryos that developed to the 1-cell stage and to the blastocyst stage were much larger for BMOCIIIvitE than BMOCIII. No significant differences in the incorporation of ${ }^{14} \mathrm{C}$-glucose or in the oxidation of ${ }^{14} \mathrm{C}$ glucose were found between the 2-cell embryos incubated in BMOCIIIvitE and BMOCIII. On the other hand, the incorporation and oxidation rates of ${ }^{14} \mathrm{C}$-glucose were significantly higher $(\mathrm{p}<0.05)$ in the embryos cultured in BMOCIIIvitE compared with those in BMOCIII at the blastocyst stage. These findings indicate that vitamin $\mathrm{E}$ has a beneficial effect on embryo development in mice, perhaps through protecting the cells from oxygen radicals in vitro.
\end{abstract}

Key words: Vitamin E, Mouse embryo, Incorporation of glucose, Oxidation of glucose

(J. Reprod. Dev. 48: 25-29, 2002)

E mbryos are able to use endogenous sources of energy or take up nutrients from the medium in which they are suspended. Evidence from a number of sources indicates that early mammalian embryos carry out oxidative phosphorylation. Glycolysis becomes important in some species in the later preimplantation stages. Evidence for aerobic metabolism is as follows. First, the preimplantation mouse embryo failed to develop in the absence of oxygen [1], or in the presence of cyanide or 2,4-dinitrophenol, both of which inhibit oxidative metabolism [2]. Second, the measurement of oxygen partial pressure in the oviduct and uterine fluids $[3,4]$ indicates that the preimplantation embryo inhabits an aerobic environment. Third, Mills and Brinster [5] showed that early mouse embryos consumed oxygen in vitro; the rate of consumption was low up to the 8cell stage, then increased dramatically. Early

Accepted for publication: September 22, 2001

Correspondence: $\mathrm{H}$. Tsujii mammalian embryos increase the production of oxygen free radicals when cultured in vitro [6].

The free radical nitric oxide (NO) is synthesized during the conversion of L-arginine to L-citrulline by the enzyme nitric oxide synthase (NOS). Three isoforms of NOS have been identified as endothelial (e)NOS, inducible (i) NOS, and neuronal (n)NOS [7-9]. Nitric oxide is known to mediate a wide variety of physiological functions, including neurotransmission and immune cell cytotoxicity [9].

Vitamin E ( $\alpha$-tocopherol and derivatives), the predominant lipid-soluble antioxidant in animal cells, protects cells from oxygen radical damage in vivo $[10,11]$ and in vitro, and is believed to be the primary free radical scavenger in mammalian cell membranes [12]. Olson and Seidel [13] reported that the development of bovine embryos in vitro improved with vitamin $\mathrm{E}$ addition.

This study describes the benefical effects of vitamin $\mathrm{E}$ on in vitro embryo development during 
the early preimplantation stages in the mouse, and on the incorporation and oxidation of glucose by embryos at these stages.

\section{Materials and Methods}

ICR strain mice 6-7 weeks old were used. Mice were maintained and used in accordance with the Guidelines for Regulation of Animal Experimentation (Faculty of Agriculture, Shinshu University). They were kept under controlled temperature $(20 \pm 1 \mathrm{C})$ and lighting $(12 \mathrm{~h}$ dark and $12 \mathrm{~h}$ light) conditions, and allowed free access to commercial solid food and tap water. Female mice were injected ip. with 5 IU pregnant mare serum gonadotrophin (Peamex, Sankyo-zoki K.K.), followed by 5 IU human chorionic gonadotrophin (hCG: Puberogen, Sankyo-zoki K.K.) 48 h later for the induction of superovulation. After hCG injection, the females were placed with a fertile male overnight and checked for the presence of copulation plugs the following morning. One to two-cell embryos and blastocysts were collected from the mice that had vaginal plugs by breaking the oviducts or by flushing the uteri at 20,30 and 95 $h$ after hCG injection.

Vitamin E ([ \pm$]-\alpha$-tocopherol; Sigma T-3251) is hydrophobic. It was first dissolved in 95\% ethanol as a 2000-strength stock solution, stored in the dark at $4 \mathrm{C}$, and then (18-20 $\mathrm{h}$ prior to embryo culture) diluted in Brinster's BMOCIII medium to a final concentration of 10,100 or $200 \mu \mathrm{M}$ vitamin $\mathrm{E}$ and $0.05 \%$ ethanol. Bovine serum albumin (Fraction V; sigma) at $5 \mathrm{mg} / \mathrm{ml}$ was added to help maintain the vitamin $\mathrm{E}$ in aqueous solution and facilitate delivery to cell plasma membranes with minimal compromise to the nature of the medium. Preliminary experiments indicated that $0.05 \%$ ethanol had no effect on mouse embryo development in vitro (data not shown).

Experiment 1: This experiment was designed to examine the effects of vitamin $\mathrm{E}$ on the in vitro development of preimplantation mouse embryos. The basic culture medium used was BMOCIII. Two-cell embryos were collected and washed three times with the same medium and transferred (10 embryos each) to a drop $(50 \mu \mathrm{l})$ of one of the following media: BMOCIII medium or BMOCIII medium supplemented with 10,100 or $200 \mu \mathrm{M}$ vitamin E. The drops were covered with paraffin oil and cultured at $37 \mathrm{C}, 5 \% \mathrm{CO}_{2}$ in air. Development of the embryos was evaluated with phase contrast microscopy (IMT-2, Olympus).

Experiment 2: This experiment was designed to examine the effect of $100 \mu \mathrm{M}$ vitamin $\mathrm{E}$ on the in vitro development of 1-cell stage embryos cultured as above.

Experiment 3: The rates of incorporation and oxidation of ${ }^{14} \mathrm{C}$-glucose were used for embryos at the two-cell and blastocyst stages according to the method of Brinster [15]. Ten embryos at each stage were transferred to a small test tube containing BMOCIII medium or BMOCIII medium supplemented with $100 \mu \mathrm{M}$ vitamin E (BMOCIIIvit E) and ${ }^{14} \mathrm{C}$-glucose (18.5 KBq: Specific activity: 1.85 $\mathrm{MBq} / \mathrm{M})$. One milliliter of hyamine was placed in another test tube and incubated for $4 \mathrm{~h}$ at $37 \mathrm{C}, 5 \%$ $\mathrm{CO}_{2}$ in air. At the end of incubation, cold PCA was added to a final concentration of $5 \%$. The acid insoluble materials were separated and washed with PCA as described above.

Radioactivity of the acid insoluble materials and hyamine were determined by a scintillation counter (LS-6500: Beckman Instruments, Inc. USA) using a scintillation cocktail (toluene: $1000 \mathrm{ml}$, POPOP: 300mg, PPO: 4 g). Eight samples were used for each observation.

The obtained data were statistically analyzed by Fischer's exact probability test in Experiments 1 and 2 and by Student's $t$-test in Experiment 3 .

\section{Results}

Experiment 1: The results of Experiment 1 are shown in Table1. BMOCIII supplemented with 100 $\mu \mathrm{M}$ vitamin $\mathrm{E}$ had a significantly higher percentage of embryos that developed to the morula and blastocyst stages than the other treatments $(p<0.05)$. There was no effect of $10 \mu \mathrm{M}$ vitamin E.

Experiment 2: The results of Experiment 2 are shown in Table 2. Embryos cultured in vitro with vitamin $\mathrm{E}$ showed a significantly higher percentage of embryos developing to morula and blastocyst stages $(\mathrm{p}<0.05)$.

Experiment 3: Results are shown in Tables 3 and 4. Both the incorporation and oxidation of ${ }^{14} \mathrm{C}$ glucose were significantly higher in BMOCIIIvitE than BMOCIII at the blastocyst stage $(p<0.05)$. The incorporation and oxidation of ${ }^{14} \mathrm{C}$-glucose were significantly higher at the blastocyst stage than at 
Table 1. Development of morula and blastocyst stage mouse 2-cell embryos cultured in medium with or without vitamin $\mathrm{E}$

\begin{tabular}{cccc}
\hline \multirow{2}{*}{$\begin{array}{c}\text { Concentrations of } \\
\text { vitamine } \mathrm{E}(\mu \mathrm{M})\end{array}$} & \multicolumn{2}{c}{$\begin{array}{c}\text { Number of } \\
\text { embryos cultured }\end{array}$} & \multicolumn{2}{c}{ Number of embryos developed (\%) } \\
\cline { 3 - 4 } & 53 & $27(50.9)^{\mathrm{b}}$ & $21(39.6)^{\mathrm{y}}$ \\
0 & 54 & $18(33.3)^{\mathrm{c}}$ & $12(22.2)^{\mathrm{z}}$ \\
10 & 53 & $33(62.3)^{\mathrm{a}}$ & $23(43.4)^{\mathrm{x}}$ \\
200 & 53 & $24(45.3)^{\mathrm{b}}$ & $20(37.7)^{\mathrm{y}}$ \\
\hline
\end{tabular}

a-c, $x-z$ : Values are highly significantly different $(p<0.05)$.

Table 2. Effect of vitamin E on development of 1-cell mouse embryos

\begin{tabular}{cccccc}
\hline Treatment & \multirow{2}{*}{$\begin{array}{c}\text { Number of embryos } \\
\text { cultured }\end{array}$} & \multicolumn{4}{c}{ Number of embryos developed (\%) } \\
\cline { 2 - 5 } & 120 & $102(85.0)$ & $73(60.8)$ & $58(48.8)$ & $39(32.5)$ \\
\hline None & 121 & $111(91.7)^{*}$ & $81(72.9)^{*}$ & $66(54.5)^{*}$ & $63(52.1)^{*}$ \\
\hline
\end{tabular}

*: Percentages with different superscripts within rows differ significantly $(\mathrm{P}<0.05)$.

Table 3. Effect of vitamin E on incorporation of ${ }^{14} \mathrm{C}$-glucose in 2-cell and blastocyst mouse embryos (Mean \pm SEM)

\begin{tabular}{cccc}
\hline $\begin{array}{c}\text { Developmental } \\
\text { stage }\end{array}$ & Vitamin E & $\mathrm{n}$ & $\begin{array}{c}\text { Incorporation } \\
{ }^{14} \text { C-glucose } \\
\text { (CPM/embryo) }\end{array}$ \\
\hline \multirow{2}{*}{ 2-cell } & - & 8 & $33.4 \pm 2.3$ \\
Blastocyst & + & 8 & $36.9 \pm 2.1$ \\
\hline
\end{tabular}

a-c: $P<0.05$ for treatments with different superscripts.

2-cell stage $(p<0.05)$ in BMOCIII and BMOCIII vitE. There were no significant effects of vitamin $E$ on the incorporation of glucose at the 2-cell stage.

\section{Discussion}

In our culture experiment, the rate of mouse embryo development from one-cell to blastocyst stage was higher in the medium supplemented with vitamin $\mathrm{E}$ than in the control medium. These findings suggest that the antioxidant vitamin $\mathrm{E}$ protects in vitro embryos from oxidative damage in $5 \% \mathrm{CO}_{2}$ in air. Olson and Seidel [13] reported that the protective effects of antioxidants with $5 \% \mathrm{O}_{2}$, $5 \% \mathrm{CO}_{2}$ and $90 \% \mathrm{~N}_{2}$ were better than with $5 \% \mathrm{CO}_{2}$ in air.
Table 4. Effect of vitamin $\mathrm{E}$ on oxidation of ${ }^{14} \mathrm{C}$-glucose in 2-cell and blastocyst mouse embryos (Mean \pm SEM)

\begin{tabular}{cccc}
\hline $\begin{array}{c}\text { Developmental } \\
\text { stage }\end{array}$ & vitamin E & $\mathrm{n}$ & $\begin{array}{c}\mathrm{CO}_{2} \text { produced } \\
(\mathrm{CPM} / \text { embryo })\end{array}$ \\
\hline 2-cell & - & 8 & $302.3 \pm 12.0^{\mathrm{a}}$ \\
Blastocyst & + & 8 & $390.8 \pm 20.8^{\mathrm{b}}$ \\
\hline a-b,c-d. P<0.05 for treatments with different superscripts.
\end{tabular}

$\mathrm{a}-\mathrm{b}, \mathrm{c}-\mathrm{d}$ : $\mathrm{P}<0.05$ for treatments with different superscripts.

More embryos developed to blastocysts when vitamin $\mathrm{E}$ was added at $100 \mu \mathrm{M}$ in Brinster's BMOCIII than at other concentrations of vitamin $\mathrm{E}$ and control. Vitamin E concentrations were based on approximate physiological levels; normal human plasma ascorbate values are 30-150 $\mu \mathrm{M}$ [16]. The concentration of vitamin E used was $\sim 4-5$ times that of normal human adult plasma levels [17] and in the range of concentration found effective for in vitro protection of rat hepatocytes (25 $\mu \mathrm{M} \alpha$-tocopheryl succinate)[18], rat conceptuses (94 $\mu \mathrm{g} / \mathrm{ml}$ or $218 \mu \mathrm{M} \alpha$-tocopherol) [19], and mouse embryos (25, $250 \mu \mathrm{M} \alpha$-tocopheryl succinate) [20]. Because vitamin $\mathrm{E}$ has poor solubility in aqueous solution, and was likely mostly bound to BSA in this system, we assumed that the actual concentration available to the cells was lower than 
the amount added.

Vitamin E was first discovered as a dietary, lipidsoluble factor that could prevent fetal death and resorption in rats [21]. In other studies, vitamin $E$ partially protected early murine embryos from the effects of heat shock [20] and a cytotoxic event mediated by free radicals [22]. Although the rate of blastocyst development under heat shock conditions was not affected by culture with vitamin E ( $\alpha$-tocopheryl succinate), the viability as determined by vital dye exclusion was improved [20]. Survival and development of rat conceptuses explanted on Day 8 of gestation were improved by culture with vitamin E [19]. These studies suggest a direct protective and developmental effect on the embryo in vitro, which may reflect a similar function in vivo.

The main biological function of vitamin $\mathrm{E}$ is probably to protect polyunsaturated fatty acids in cell membranes. Peroxidation of these membrane lipids can lead to structural damage, affecting function and permeability of membranes, eventually resulting in irreversible cell injury and death.

In vitro, vitamin E molecules have been subjected to free radical attack [23]. Deleterious effects of oxygen radicals on in vitro development of embryos have been reported in various laboratory and domestic animals such as the mouse [24], rabbit [25] and pig [26]. The authors speculate that superoxide radicals are involved in the mouse 2-cell developmental block, because the addition of free radical scavengers such as thioredoxin [27] or SOD [28] to culture medium increased the number of embryos that developed beyond the block.

It is known that the oxygen concentration within the reproductive tract of mammals is lower than that in air. For instance, the $\mathrm{O}_{2}$ concentration within the tract of rabbits [29] and rhesus monkeys [30] was reported to be 10 to $60 \mathrm{mmHg}$, an $\mathrm{O}_{2}$ concentration of about 5\% [31]. Furthermore, the cleaving mouse embryo has a maximal oxygen requirement in vitro of approximately $5 \%$, and blastocysts developed under $20 \% \mathrm{O}_{2}$ had fewer cells than those developed under $5 \% \mathrm{O}_{2}$ [32].

In the mouse, pyruvate is essential for the survival of unfertilized and fertilized oocytes and for the first cleavage. Lactate acts synergistically with pyruvate and, as the sole substrate, lactate can support the cleavage of 2-cell mouse embryos. Glucose as the sole substrate cannot support development until the 4- and 8-cell stages.

Schini and Bavister [33] and Seshagiri and Bavister [34, 35] postulated that glucose inhibits TCA cycle activity through a phenomenon known as the Crabtree effect. This effect is the result of depletion of the inorganic phosphate pool by glycolytic uptake [36]. An alternative explanation lies in the allosteric inhibition of glycolytic enzymes, such as phosphofructokinase and hexokinase, observed in the Pasteur effect [27]. This is the proposed mechanism for the glycolytic block in precompaction mouse embryos [38, 39].

The findings obtained in Experiment 3 demonstrate that the kinetics of glucose use change during preimplanation development. This may reflect differences in either uptake mechanisms or metabolic enzyme activities, or both. Nevertheless, it is of interest that even though the relative use of glucose is much higher in blastocysts than in 2-cell embryos, a higher concentration of exogenous glucose is required for the saturation of the pathways in 8-cell embryos.

\section{References}

1. Auerbach S, Brinster RL. Effect of oxygen concentration on the development of two-cell mouse embryos. Nature 1968; 217: 465-466.

2. Thomson JL. Effect of inhibitors of carbohydrate metabolism on the development of preimplantation mouse embryos. Exp Cell Res 1967; 46: 252-262.

3. Leese HJ. The formation and function of oviduct fluid. J Reprod Fertil 1987; 82: 843-856.

4. Yochim JM. Intrauterine oxygen tension and metabolism of the endometrium during the preimplantation period. In: Balandau RJ (ed.), The
Biology of the Blastocyst. University of Chicago Press; 1971: 363-382.

5. Mills RM, Brinster RL. Oxygen consumption of preimplantation mouse embryos. Exp Cell Res 1968; 47: 337-344.

6. Sellens MH, Stein S, Sherman MI. Protein and free amino acid content in preimplantation mouse embryos and in blastocysts under various culture conditions. J Reprod Fertil 1981; 61: 307-315.

7. Mocada S, Higgs A. The L-arginine-nitric oxide pathway. N Eng J Med 1993; 329: 2002-2012. 
8. Vane JR, Anggard EE, Botting RM. Regulatory functions of the vascular endothelium. $N$ Engl J Med 1990; 323: 27-36.

9. Lowenstei CJ, Dinerman JL, Snyder SH. Nitric oxide: A physiologic messenger. Ann Intern Med 1994; 120: 227-237.

10. Chow CK. Nutritional influence on cellular antioxidant defense systems. Am J Clin Nutr 1979; 32: 1006-1081.

11. Miller JK, Brzezinska-Slebodzinska E. Oxidative stress, antioxidants and animal function. J Dairy Sci 1993; 76: 2812-2823.

12. Chow CK. Vitamin E and oxidative stress. Free Radical Biol Med 1991; 11: 215-232.

13. Olson SE, Seidel GE Jr. Reduced oxygen tension and EDTA improve bovine zygote development in a chemically defined medium. J Anim Sci 2000; 78: 152-157.

14. Brinster RL. Measuring embryonic activity. In: Daniel JC Jr. (ed.), Method in Mammalian Embryology. San Francisco, California, Freeman; 1972: 215-227.

15. Brinster RL. Carbon dioxide production from glucose by the preimplantation mouse embryo. Exp Cell Res 1967; 47: 271-277.

16. Scis H, Stah W, Sundquist AR. Antioxidant function of vitamins. Ann NY Acad Sci 1992; 669: 720.

17. Bieri JG, Farrel PM. Vitamin E. In: Munso PL, Glover J. Diczfalusy E, Olson RJ (eds.), Advances in Vitamins and Hormones in Reseach and Applications. New York: Academic Press; 1976: 3175.

18. Fariss MW. Oxygen toxicity: Unique cytoprotectiv properties of vitamin E succinate in hepatocytes. Free Radical Biol Med 1990; 9: 333-343.

19. Steele CE, Jefferys EH, Diplock AT. The effect of vitamin $\mathrm{E}$ and synthetic antioxidants on the growth in vitro of explanted rat embryos. J Replod Fertil 1974; 38: 115-123.

20. Arechiga CG, Ealy AD, Hansen PJ. Efficacy of vitamin $\mathrm{E}$ and glutathione for thermoprotection of murine morulae. Theriogenology 1994; 41: 1545-1553.

21. Evans HM, Bishop KS. On the existence of a hitherto unrecognized dietary factor essential for reproduction. Science; 1922; 56: 650-653.

22. Loven DP. A role for reduced oxygen species in heat-induced cell killing and the induction of thermo tolerance. Med Hypothese 1988; 26: 39-50.

23. Machlin LJ, Gabriel E. Interactions of vitamin $E$ with vitamin $C$, vitamin $B_{12}$, and zinc. In: Levander OA, Cheng L (eds.), Micronutrient Interactions: Vitamins. Minerals and Hazardous Elements. Ann NY Acad Sci 1980; 355: 98-108.
24. Umaoka Y, Noda Y, Narimot K, Mori T. Effects of oxygen toxicity on early development of mouse embryos. Mol Replod Dev 1992; 31: 28-33.

25. Li J, Foote RH. Culture of rabbit zygotes into blastocysts in protein-free medium with one to twenty per cent oxygen. J Reprod Fertil 1993; 98: 163167.

26. Reed ML, Illera MJ, Petters RM. In vitro culture of pig embryos. Theriogenology 1992; 37: 95-109.

27. Natsuyama S, Noda $Y$, Narimoto $K$, Umaoka $Y$, Mori T. Release of two-cell block by reduction of protein disulfide with thioredoxin from Escherichia coli in mice. J Reprod Fertil 1992; 95: 649-656.

28. Noda Y, Matsumoto H, Umaoka Y, Tasumi K, Kish J, Mori T. Involvement of superoxide radicals in the mouse two-cell block. Mol Reprod Dev 1991; 28: 356360.

29. Mastroianni L Jr, Jones R. Oxygen tension within the rabbit fallopian tube. J Reprod Fertil 1965; 9: 99102.

30. Maas DHA, Storey BT, Mastroianni L Jr. Oxygen tension in the oviduct of the rhesus monkey (Macaca mulatta). Fertil Steril 1976; 27: 1312-1317.

31. Kessler M. Oxygen supply to tissue in normoxia and in oxygen deficiency. Microvasc Res 1974; 8: 283290.

32. Quinn P, Harlow GM. The effect of oxygen on the development of preimplantation mouse embryos in vitro. J Exp Zool 1978; 206: 73-80.

33. Schini SA, Bavister BD. Two-cell block to development of cultured hamster embryos is caused by phosphate and glucose. Biol Reprod 1988; 39: 1183-1192.

34. Seshagiri PB, Bavister BD. Glucose inhibits development of hamster 8-cell embryos in-vitro. Biol Reprod 1989; 40: 599-606.

35. Seshagiri PB, Bavister BD. Phosphate is required for inhibition of glucose development of hamster 8cell embryos in-vitro. Biol Reprod 1989; 40: 607-614.

36. Koobs DH. Phosphate mediation of the Crabtree and Pasteur effects. Science 1972; 178: 127-133.

37. Krebps HA. The Pasteur effect of the relations between respiration and fermentation. In: Campbell PN, Dickens F (eds.), Essays in Biochemistry, New York, Academic Press; 1972: 8: 1-34.

38. Barbehenn EK, Wales RG, Lowry OH. The explanation for the blockade of glycolysis in early mouse embryos. Proc Natl Acad Sci USA 1974; 71: 1056-1060.

39. Barbehenn EK, Wales RG, Lowry OH. Measurement of metabolites in single preimplantation embryos; a new means to study metabolic control in early embryos. J Embryol Exp Morphol 1978; 43: 2946. 